University of Nebraska - Lincoln

DigitalCommons@University of Nebraska - Lincoln

Evaluation of hha and hha sepB mutant strains of Escherichia coli 0157:H7 as bacterins for reducing E. coli 0157:H7 shedding in cattle

\author{
Vijay K. Sharma \\ United States Department of Agriculture, vijay.sharma@ars.usda.gov \\ Evelyn A. Dean-Nystrom \\ Pre-Harvest Food Safety and Enteric Diseases Research Unit, evelyn.nystrom@ars.usda.gov \\ Thomas A. Casey \\ United States Department of Agriculture
}

Follow this and additional works at: https://digitalcommons.unl.edu/usdaarsfacpub

Part of the Agricultural Science Commons

Sharma, Vijay K.; Dean-Nystrom, Evelyn A.; and Casey, Thomas A., "Evaluation of hha and hha sepB mutant strains of Escherichia coli 0157:H7 as bacterins for reducing E. coli 0157:H7 shedding in cattle" (2011). Publications from USDA-ARS / UNL Faculty. 940.

https://digitalcommons.unl.edu/usdaarsfacpub/940

This Article is brought to you for free and open access by the U.S. Department of Agriculture: Agricultural Research Service, Lincoln, Nebraska at DigitalCommons@University of Nebraska - Lincoln. It has been accepted for inclusion in Publications from USDA-ARS / UNL Faculty by an authorized administrator of DigitalCommons@University of Nebraska - Lincoln. 


\title{
Evaluation of hha and hha sepB mutant strains of Escherichia coli 0157:H7 as bacterins for reducing E. coli O157:H7 shedding in cattle ${ }^{\text {ir }}$
}

\author{
Vijay K. Sharma*, Evelyn A. Dean-Nystrom, Thomas A. Casey \\ Food Safety and Enteric Pathogens Research Unit, National Animal Disease Center, Agricultural Research Service, \\ United States Department of Agriculture, Ames, IA 50010, USA
}

\section{A R T I C L E I N F O}

\section{Article history:}

Received 29 September 2010

Received in revised form 1 April 2011

Accepted 10 April 2011

Available online 6 May 2011

\section{Keywords:}

Bacterins

LEE

0157

\begin{abstract}
A B S T R A C T
Escherichia coli 0157:H7 colonizes cattle intestines by using the locus of enterocyte effacement (LEE)encoded proteins. The induction of systemic immune response against $L E E$-encoded proteins, therefore, will prove effective in reducing E. coli 0157:H7 colonization in cattle. The previous studies have demonstrated that a $h$ ha (encodes for a hemolysin expression modulating protein) deletion enhances expression of $L E E$-encoded proteins and a $\operatorname{sep} B$ (encodes an ATPase required for the secretion of $L E E$-encoded proteins) deletion results in intracellular accumulation of LEE proteins. In this study, we demonstrate the efficacy of the hha and hha sepB deletion mutants as bacterins for reducing fecal shedding of E. coli 0157:H7 in experimentally inoculated weaned calves. The weaned calves were injected intramuscularly with the bacterins containing $10^{9}$ heat-killed cells of the $h h^{+}$wild-type or hha or hha sepB isogenic mutants, and boosted with the same doses 2- and 4-weeks later. The evaluation of the immune response two weeks after the last booster immunization revealed that the calves vaccinated with the hha mutant bacterin had higher antibody titers against LEE proteins compared to the titers for these antibodies in the calves vaccinated with the hha sepB mutant or $h h^{+}$wild-type bacterins. Following oral inoculations with $10^{10}$ $\mathrm{CFU}$ of the wild-type E. coli $0157: \mathrm{H7}$, the greater numbers of calves in the group vaccinated with the hha or hha sеpB mutant bacterins stopped shedding the inoculum strain within a few days after the inoculations compared to the group of calves vaccinated with the $h h a^{+}$wild-type bacterin or PBS sham vaccine. Thus, the use of bacterins prepared from the hha and hha sepB mutants for reducing colonization of $E$. coli 0157:H7 in cattle could represent a potentially important pre-harvest strategy to enhance post-harvest safety of bovine food products, water and produce.
\end{abstract}

Published by Elsevier Ltd.

\section{Introduction}

Escherichia coli 0157:H7 are Shiga toxin-producing zoonotic pathogens capable of causing gastroenteritis of varied severity in humans of all age groups [1]. Adult cattle are asymptomatic carriers of E. coli 0157:H7 and these animals serve as major sources for this pathogen [2]. The major sites for E. coli 0157:H7 colonization of bovine intestines include terminal rectum and cecum [3-5]. Cattle colonized with E. coli 0157:H7 excrete these bacteria in their feces for variable durations and magnitudes, which in turn increases the risk of hide contamination and contamination of carcasses during

\footnotetext{
Disclaimer: Mention of trade names or commercial products in this article is solely for the purpose of providing specific information and does not imply recommendation or endorsement by the U.S. Department of Agriculture.

* Corresponding author at: USDA, ARS, National Animal Disease Center, 1920 Dayton Avenue, Bldg. 24, P.O. Box 70, Ames, IA 50010, USA. Tel.: +1 515337 7406; fax: +1 5153377438

E-mail address: vijay.sharma@ars.usda.gov (V.K. Sharma).
}

meat processing operations [6]. The intimate adherence of $E$. coli 0157:H7 bacteria to epithelial cells results in the production of characteristic attaching and effacing (A/E) lesions [3,7,8].

A 43-kb pathogenicity island termed the locus of enterocyte effacement ( $L E E$ ) encodes factors essential for the formation of $\mathrm{A} / \mathrm{E}$ lesions on intestinal epithelial cells [9-11]. LEE, which contains five major operons ( $L E E 1$ to $L E E 5$ ), encodes for a type III secretion system (T3SS), translocated intimin receptor (Tir), intimin, and secreted proteins EspA, EspB, EspD [12,13]. The protein EspA, an integral component of T3SS, forms tubular structures at the bacterial cell surface for delivering Esp proteins and Tir into intestinal epithelial cells [14]. Tir is inserted into the epithelial cell membrane where it interacts with intimin (an auto-transporter) located on the bacterial cell surface to facilitate intimate adherence between bacterial and epithelial cells $[15,16]$. The proteins secreted by T3SS cause cytoskeletal changes in epithelial cells resulting in the production of A/E lesions [17]. Several genetic factors regulate $L E E$ expression by directly or indirectly affecting the expression of Ler, LEE1-encoded positive regulator of $L E E$ [18]. In recent reports, we demonstrated that a deletion of hha resulted in an increased transcription of $L E E$ 
[19] and allowed increased adherence of the mutant E. coli O157:H7 strain to HEp-2 cells [20]

Numerous studies have demonstrated the requirement for $L E E$ encoded proteins in adherence and colonization by E. coli 0157:H7 of epithelial cells using in vitro adherence assays and animal models. For example, the sepB deletion mutants of E. coli 0157:H7 are unable to secrete the $L E E$-encoded adherence factors and are thus compromised in their ability to adhere to epithelial cells and to colonize animal intestines $[11,12,21]$. SepB, which is encoded by the $L E E 3$ operon, functions as an ATPase to generate energy for the T3SS to secrete LEE proteins [12]. In another study, calves inoculated with a library of signature-tagged mutants of $E$. coli 0157:H7 showed that 13 of 59 mutants impaired in their ability to colonize bovine gastrointestinal tracts had these mutations clustered in the genes encoded by LEE [21]. Similarly, the inoculation of calves, rabbits, or pigs with E. coli 0157:H7 mutants disrupted or deleted in genes eae, espA, espB, or tir or various combinations of these genes abolished or reduced the ability of these mutants to colonize intestines of these animals [7,17,22-28]. The importance of $L E E$-encoded factors in intestinal colonization was also demonstrated in animals that could no longer be colonized or were colonized at reduced levels by E. coli 0157:H7 because of the presence of circulating or mucosal antibodies (produced either by vaccination or maternally acquired) to one or more $L E E$-encoded proteins [29-32].

Epidemiological surveys conducted over the past several years indicate that E. coli 0157:H7 is ubiquitous at the herd level in both dairy and beef cattle operations but prevalence of these bacteria in individual animals or animals in pens varies greatly [33-36]. Thus, application of strategies for reducing pre-harvest prevalence of $E$. coli $0157: \mathrm{H} 7$ at the farm is important for enhancing safety of bovine food products and mitigating economic impact of $E$. coli 0157:H7 caused disease outbreaks on the public health system and the food industry [37].

Since $L E E$-encoded proteins are critical in gastrointestinal colonization of cattle by E. coli $0157: H 7$, several studies have reported evaluations of vaccines containing one or more LEE-encoded proteins to reduce intestinal colonization in cattle experimentally or naturally infected with E. coli O157:H7 [31,38-41]. However, only one such $L E E$-based vaccine, called EconicheTM, has been granted a full license for use in cattle feedlots in Canada (Bioniche Life Sciences, Inc., Belleville, Ontario, Canada). The EconicheTM vaccine is a protein cocktail prepared by concentrating T3SS-secreted proteins from culture supernatants of $E$. coli 0157:H7. Three dose regimens ( $50 \mu \mathrm{g}$ of secreted proteins per dose) of this vaccine had been tested for its effectiveness in reducing E. coli O157:H7 shedding in cattle housed under experimental conditions and in feedlots. Cattle housed under experimental conditions showed enhanced immune response to several constituent secreted proteins of the cocktail that correlated with a significant reduction in the duration and magnitude of fecal shedding of E. coli 0157:H7 [40]. Similarly, a significant reduction in the prevalence of $E$. coli $0157: \mathrm{H7}$ was observed in vaccinated versus unvaccinated feedlot cattle [41]. A non-LEE based vaccine containing siderophore receptors and porins of $E$. coli outer membranes had also been shown to be effective in reducing shedding of $E$. coli 0157:H7 in feedlot cattle [42].

In this study, we constructed hha and hha sepB deletion mutants of a $h h a^{+}$wild-type strain of E. coli 0157:H7 and determined the effects of these mutations on the secretion of $L E E$-encoded proteins Tir, EspA, EspB and intimin. We used these mutants as heat-killed preparations, referred to as bacterins hereafter, for intramuscular immunization of cattle and determined the impact of these vaccinations on fecal shedding of $E$. coli $0157: \mathrm{H} 7$ relative to that in cattle vaccinated either with a $h h a^{+}$wild-type bacterin or a PBS sham vaccine. In addition, we determined relative titers of circulating IgG antibodies in vaccinated cattle to assess the relative importance of various $L E E$-encoded proteins in inducing immune responses effective in reducing fecal shedding of E. coli O157:H7.

\section{Methods}

\subsection{Bacterial strains, plasmids, and growth conditions}

Table 1 lists the bacterial strains and plasmids used in this study. All $E$. coli strains were propagated at $37^{\circ} \mathrm{C}$ in Luria-Bertani broth (LB) or LB containing 1.5\% agar. For liquid cultures, colonies from LB agar plates were inoculated into LB broth and incubated at $37^{\circ} \mathrm{C}$, unless stated otherwise, on a shaker at $200 \mathrm{rpm}$. Dulbecco's Modified Eagle Medium (DMEM) or M9+ Medium (minimal salts plus $1 \%$ casamino acids) were used for the optimal production of LEE proteins in the liquid cultures [43]. Media were supplemented, when required, with selective antibiotics at the following concentrations: ampicillin $50 \mu \mathrm{g} / \mathrm{ml}$; kanamycin $50 \mu \mathrm{g} / \mathrm{ml}$; and streptomycin $100 \mu \mathrm{g} / \mathrm{ml}$.

\subsection{Primer design and $P C R$ amplification}

The primers used in this study are listed in Table 1 . These primer sequences were selected from the published sequence of $E$. coli 0157:H7 EDL933 genome [44], and were synthesized by Integrated DNA Technologies (Coralville, IA). The PCR mixture contained $5 \mu \mathrm{l}$ of DNA $(0.1 \mu \mathrm{g}), 0.3 \mu \mathrm{M}$ each of forward and reverse primers, $15 \mathrm{mM}$ Tris- $\mathrm{HCl}$ ( $\mathrm{pH} 8.0$ ), $50 \mathrm{mM} \mathrm{KCl}, 3.0 \mathrm{mM} \mathrm{MgCl}_{2}, 200 \mu \mathrm{M}$ of each of the four dNTPs (Roche Diagnostic Corporation, Indianapolis, IN), and 1.25 units of AmpliTaq Gold polymerase (PE Biosystems, Foster City, CA). The PCR amplification was performed by heating the PCR mixture to $95^{\circ} \mathrm{C}$ for $10 \mathrm{~min}$ followed by 40 cycles of heating $\left(94^{\circ} \mathrm{C}\right.$ for $\left.30 \mathrm{~s}\right)$, annealing $\left(55^{\circ} \mathrm{C}\right.$ for $\left.30 \mathrm{~s}\right)$, extension $\left(72^{\circ} \mathrm{C}\right.$ for 60 s per $1000 \mathrm{bp}$ amplification), and termination $\left(72^{\circ} \mathrm{C}\right.$ for $\left.5 \mathrm{~min}\right)$. The PCR amplified products were resolved by the standard agarose gel electrophoresis. The DNA fragments of the predicted sizes were extracted from the agarose gel by a QIAquick Gel Extraction Kit according to the manufacturer's instructions (Qiagen, Valencia, CA), and concentrations of purified DNA fragments were determined using a spectrophotometer (NanoDrop Technologies, Wilmington, DE).

\subsection{Construction of hha and hha sepB deletion mutants}

The hha deletion mutant of $E$. coli 0157:H7 strain 86-24 $\Delta$ stx2 (Table 1 ) was constructed by using plasmid pSM122 and the allelic replacement procedure described in a previous study [19]. We used the same allelic replacement procedure to delete sepB in E. coli 0157:H7 strain 86-24 $\Delta$ stx2 $\Delta$ hha (Table 1). To delete sepB, we PCR amplified a DNA fragment containing 1500-bp upstream (US-fragment) of the start codon and another fragment containing 1500-bp downstream (DS-fragment) of the stop codon of $\operatorname{sep} B$ by using the primers VS545/VS546 and VS547/VS548, respectively. The US- and DS-fragments were cloned into pCR-XL/TOP10 cloning system to generate plasmids pSM281 and pSM282, respectively, according to manufacturer's instructions (Invitrogen Corporation, Carlsbad, CA). The US-fragment of pSM281 was recovered by using the restriction endonucleases BamHI (restriction site present in pCR-XL multiple cloning site immediate upstream of $5^{\prime}$ end of US-fragment) and Sall (restriction site created at the $3^{\prime}$ end of USfragment by primer VS546). The BamHI and Sall US-fragment was then cloned at the corresponding BamHI (vector) and Sall restriction (created by the primer VS548 at the $5^{\prime}$ end of DS-fragment of pSM282) sites to generate the plasmid pSM284 (Table 1). The 3$\mathrm{kb}$ fragment containing both the US- and DS-fragments in tandem (5' US-DS 3') was then isolated from pSM284 using Xbal, restriction site created by the primers VS547 and VS545 at the $5^{\prime}$ and $3^{\prime}$ 
Table 1

Bacterial strains, plasmids ${ }^{\mathrm{a}}$, and primers.

\begin{tabular}{|c|c|c|}
\hline Strain or plasmid & Genotype and description & Source or reference \\
\hline \multicolumn{3}{|l|}{ E. coli strains } \\
\hline E. coli $0157: \mathrm{H7}$ strain $86-24$ & $s t \times 2^{+}$ & {$[56]$} \\
\hline Strain $86-24 \Delta s t \times 2$ & $86-24$ deleted of $s t \times 2$ & [19] \\
\hline Strain 86-24 $\Delta s t \times 2 \Delta h h a$ & $86-24$ deleted of $s t x 2$ and $h h a$ & This study \\
\hline Strain 86-24 $\Delta$ stx2 $\Delta$ hha $\Delta \operatorname{sepB}$ & 86-24 deleted stx2, hha, and sepB & This study \\
\hline TOP 10 & endA1 recA1 hsdR17 $\left(\mathrm{r}_{\mathrm{K}}^{-} \mathrm{m}_{\mathrm{K}}^{-}\right)$supE44 & Invitrogen \\
\hline \multicolumn{3}{|c|}{ - } \\
\hline pCR-XL & Cloning vector & Invitrogen \\
\hline pAM450 & Temperature-sensitive allelic replacement vector & {$[25]$} \\
\hline pSM122 & pAM450 derivative used for deleting $h h a$ & [19] \\
\hline pSM281 & $1.5-\mathrm{kb}$ sequence located upstream of $\operatorname{sepB}(\mathrm{escN})$ cloned in $\mathrm{pCR}-\mathrm{XL}$ & This study \\
\hline pSM282 & $1.5-\mathrm{kb}$ sequence located downstream of $\operatorname{sepB}(\mathrm{escN})$ cloned in pCR-XL & This study \\
\hline pSM284 & $1.5-\mathrm{kb}$ sequence of pSM282 cloned downstream of $1.5-\mathrm{kb}$ sequence of pSM281 & This study \\
\hline pSM302 & $\begin{array}{l}\text { 3-kb sequence of pSM284 containing upstream and downstream sequences of } \\
\operatorname{sepB}(\operatorname{escN}) \text { cloned in pAM450 }\end{array}$ & This study \\
\hline \multicolumn{3}{|l|}{ Primers used for PCR amplification } \\
\hline Primer & Nucleotide sequence $\left(5^{\prime}-3^{\prime}\right)^{\mathrm{b}}$ & Location $(\mathrm{bp})^{\mathrm{c}}$ \\
\hline VS501 & ACGTTTGGCTTATTGGCTCTG & $4676296-4676276$ \\
\hline VS545 & GCGTCTAGAGCGCGCAGGCGTTATTGACCC & $4677526-4677546$ \\
\hline VS546 & GCGGTCGACTTACCGTTCCTAATACTTTAAGTTCG & $4676018-4676043$ \\
\hline VS547 & GCGTCTAGACGCAACATGTGTATATCAATATGGAC & $4673159-4673184$ \\
\hline VS548 & GCGGTCGACGTATGTTGGACAGAATTTATCTATTC & $4674675-4674650$ \\
\hline VS561 & CACCAGCGATGCACAATATGCCTG & $4674507-4674530$ \\
\hline
\end{tabular}

a The detailed descriptions of bacterial strains and plasmids listed in this table is provided under Section 2.

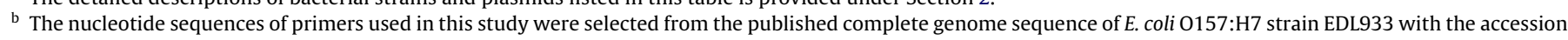
number AE005174.2.

${ }^{c}$ Location refers to the position of primer sequence in the genome of EDL933.

ends, respectively, and cloned into the $\mathrm{Xbal}$ site of a temperaturesensitive plasmid pAM450 (Table 1) to generate a recombinant plasmid pSM302. The plasmid pSM302 was electroporated into E. coli 0157:H7 strain 86-24 $\Delta$ stx2 $\Delta$ hha, and the new strain 86$24 \Delta$ stx2 $\Delta h h a /$ pSM302 was cultured under growth conditions, as described previously [19], that facilitated deletion of the chromosomal copy of sepB. The deletion of sepB was confirmed by PCR using the primers VS501 and VS561 (Table 1).

\subsection{Precipitation and quantification of secreted proteins and preparation of whole-cell lysates}

The bacterial strains were grown in M9+ or DMEM media at $37^{\circ} \mathrm{C}$ overnight and diluted 1:500 into fresh M9 or DMEM media and incubated at $37^{\circ} \mathrm{C}$ for $6 \mathrm{~h}$. The cultures were adjusted to $A_{600} \mathrm{~nm}$ of 1.0 and centrifuged at $10,000 \times g$ for $10 \mathrm{~min}$. The cell pellets were resuspended in $1 \mathrm{ml}$ of TBS $(0.1 \mathrm{M}$ Tris, $0.154 \mathrm{M} \mathrm{NaCl}, \mathrm{pH} 7.4)$ and stored at $-20^{\circ} \mathrm{C}$ until used for making the whole-cell lysates. The culture supernatants were mixed with tricholoroacetic acid (TCA) to a final concentration of $10 \%$, incubated overnight at $4{ }^{\circ} \mathrm{C}$, and centrifuged for $30 \mathrm{~min}(10,000 \times \mathrm{g})$. After discarding supernatants, the TCA pellets were resuspended in $0.1 \mathrm{M}$ TBS and then stored at $-20^{\circ} \mathrm{C}$. The protein content of resuspended TCA precipitates was estimated from $A_{280 \mathrm{~nm}}$ measurements of these samples.

\subsection{SDS-PAGE and Western blotting}

Two-volumes of TBS-suspended cell pellets or TCA precipitated proteins, prepared from the cultures adjusted to $A_{600 \mathrm{~nm}}$ of 1.0 as described above, were mixed with one-volume of SDS sample buffer (Invitrogen Corporation, Carlsbad, CA) and incubated at $95^{\circ} \mathrm{C}$ for $5 \mathrm{~min}$. The boiled samples were loaded into the wells of a $10-20 \%$ Tris-Tricine (Invitrogen Corporation, Carlsbad, CA) or 4-20\% Trisbuffered (Biorad Laboratories, Hercules, CA) SDS-polyacrylamide gels. The gels were subjected to electrophoresis using a SDS-PAGE running buffer (Invitrogen Corporation, Carlsbad, CA) at a constant voltage to resolve proteins present in the whole-cell lysates or TCA-precipitates of culture supernatants. The gels were either stained with Coomassie brilliant blue to visualize the presence of total proteins or used for transferring the proteins to nitrocellulose membranes (Schleicher and Schuell, Inc., Keene, $\mathrm{NH}$ ) using a standard western blotting procedure.

\subsection{Detection of T3SS secreted LEE proteins}

The nitrocellulose membranes, following the western blotting of proteins, were secured and processed in a multichannel miniblotter according to the manufacturer's instructions (Immunetics, Boston, MA). The unbound sites on the membranes were blocked by adding $50 \mu \mathrm{l}$ of TBS-T (TBS containing $0.05 \%$ Tween 20) [29] to each well for $5 \mathrm{~min}$. The blocking step was repeated for a total of $3 \times 5 \mathrm{~min}$. For detecting the presence of $L E E$-encoded proteins in whole-cell lysates or TCA-precipitated culture supernatants of the $h h a^{+}$wild-type and hha and hha sepB mutant strains, $50 \mu l$ of rabbit antibodies (diluted 1:5000 in TBS-T) prepared against purified EspA, EspB (kindly provided by Dr. Jorge Giron, University of Florida, Gainesville, FL), Tir and intimin (kindly provided by Dr. Alison O'Brien, Uniformed Services University of the Health Sciences, Bethesda, MD) were added to individual tracks for detecting EspA, $\mathrm{EspB}$, Tir, and intimin. After $60 \mathrm{~min}$ of incubation at the room temperature, the unbound antibodies were washed off by adding $50 \mu \mathrm{l}$ of TBS-T to each track and letting it incubate for $5 \mathrm{~min}$. The washing was repeated for two additional times. Fifty $\mu$ l of biotinylated goat anti-rabbit IgG (Vector Laboratories, Inc., Burlingame, CA) diluted in $0.4 \%$ Block Ace in TBS-T (Serotec, Oxford, UK) was added to each well. Following incubation at the room temperature for $30 \mathrm{~min}$, the membranes were washed with TBS-T $(3 \times 5 \mathrm{~min})$, and removed from the blotter. The membranes were developed using Vector ABC staining kit according to the manufacturer's instructions (Vector Laboratories, Inc., Burlingame, CA).

\subsection{Detection of antibodies against LEE-encoded proteins in sera of vaccinated animals}

The western-blotted nitrocellulose membranes containing transferred TCA-precipitated proteins (described above) were used 
for determining anti-intimin, anti-Tir, anti-EspA, and anti-EspB titers in the sera prepared from the blood collected at pre- and four weeks post-vaccination of calves with bacterins. These blots were processed as described above with the exception that the diluted pre- and post-immune sera $(100 \mu \mathrm{l}$ of $1: 100,1: 500$, and $1: 1000$ dilution in TBS-T) were used as a source of primary antibodies and the biotinylated goat anti-bovine IgG was used as a secondary antibody. After washing $(3 \times 5 \mathrm{~min})$, the membranes were developed using Vector ABC staining kit (Vector Laboratories, Inc., Burlingame, $\mathrm{CA}$ ), and the intensities of the colored bands produced on the membranes were determined on ChemiDoc Imager (BioRad) using a QuanityOne software.

\subsection{Preparation of bacterins}

The $h h^{+}$wild-type and $h h a$ and $h$ ha sepB mutant strains of E. coli 0157:H7) were propagated overnight in LB broth containing $100 \mu \mathrm{g}$ per $\mathrm{ml}$ of streptomycin in a shaker-incubator $\left(37^{\circ} \mathrm{C}, 200 \mathrm{rpm}\right)$. The overnight culture of each strain was diluted 1:100 in DMEM and incubated at $37^{\circ} \mathrm{C}$ for $6 \mathrm{~h}$ (200 rpm). The cultures were centrifuged at $5000 \times g$ for $10 \mathrm{~min}$, supernatants removed and the cell pellets resuspended in phosphate-buffered saline (PBS) to one-tenth the volume of the original culture. An aliquot of the PBS-bacterial cell suspension was diluted (10-fold serial dilutions), plated on LB agar containing streptomycin, and incubated overnight at $37^{\circ} \mathrm{C}$. The number of colonies that grew on these plates provided total viable cell counts of these bacterial suspensions. The remainder of the PBS suspension was incubated in a heated water-bath $\left(80^{\circ} \mathrm{C}\right)$ for $30 \mathrm{~min}$ to kill bacterial cells. One hundred $\mu \mathrm{l}$ aliquots of heated cell suspensions were plated on LB agar containing streptomycin and incubated overnight at $37^{\circ} \mathrm{C}$ to confirm that the heated cells were not viable. Based on the viable cell counts, the remainder of the heat-killed suspension was adjusted to about $10^{9}$ cells per $\mathrm{ml}$ before storing at $-4{ }^{\circ} \mathrm{C}$.

\subsection{Vaccination of calves and detection of antibodies directed against LEE-encoded proteins in vaccinated calves}

The weaned male calves (8-10 weeks in age) were purchased from local farms in Iowa and were housed in accordance with the guidelines of the American Association for Laboratory Animal Care. The calves were housed in pairs in climate-controlled BL-2 barns and were allowed to acclimate for 2-weeks to the animal housing environment prior to experimentation. The calves were fed twice daily with both the pelleted feed and alfalfa hay cubes in amounts ( $16 \%$ crude protein, $2.5 \%$ crude fat, $8 \%$ fiber) equal to $1 \%$ of their body weights, and water was offered ad libitum. All animal protocols were approved by the National Animal Disease Center Animal Care and Use Committee. In each of the three vaccine trials conducted, eight calves were divided into four groups of two calves each. The blood samples were taken from the jugular vein as preinoculum samples. While the calves in the group 1 were injected with 1-ml of phosphate-buffered saline (PBS), the calves in groups 2,3 , and 4 were injected with the heat-killed vaccines (containing $10^{9}$ cells $/ \mathrm{ml}$ ), called bacterins, prepared from the $h \mathrm{ha}^{+}$wild-type, or hha, or hha sepB mutant strains, respectively. The use of bacterins at $10^{9}$ cells per $\mathrm{ml}$ in the current study was based on the previously published reports describing the effectiveness of an $E$. coli J-5 bacterin for its protective effects in calves from mastitis and endotoxin-caused diseases [45,46]. All injections were administered intramuscularly in the neck using an 18-Gauge needle attached to a syringe. All animals were revaccinated at week 2 and 4 post initial vaccination. The blood samples were collected two weeks post-second vaccination and the sera prepared from these blood samples were used for measuring the IgG titers against intimin, Tir, EspA, and EspB by immunoblotting as described above.

\subsection{Determination of fecal shedding of E. coli 0157:H7 in vaccinated calves}

Two weeks after the third booster dose of the bacterins, all calves were administered gelatin capsules containing $1-\mathrm{ml}\left(10^{10} \mathrm{CFU}\right)$ of a culture of a wild-type E. coli $0157: \mathrm{H7}$ (strain 86-24) and a few feed pellets. A balling gun was used for delivering the capsules into the calf pharynx. The feces were collected everyday for two weeks by the rectal palpation of calves. Ten-fold serial dilutions of feces were prepared in PBS and $100 \mu \mathrm{l}$ aliquots plated on duplicate sets of Sorbitol MacConkey agar containing $100 \mu \mathrm{g} / \mathrm{ml}$ of streptomycin. After incubating plates at $37^{\circ} \mathrm{C}$ for $24 \mathrm{~h}$, white, sorbitol-negative colonies were counted for determining viable colony forming units (CFU) of E. coli 0157:H7 in feces. Several colonies were randomly picked and tested for agglutination with an E. coli 0157:H7-specific antiserum (Oxoid, Unipath Ltd., Ogdensburg, NY). The sensitivity of detection was $10^{2}$ bacterial CFU/g of feces.

\subsection{Statistics}

The significance of the differences in the outcome variables, such as the numbers of animals shedding or the duration of shedding of E. coli 0157:H7 in feces among animals vaccinated with different bacterins, was determined using an Unpaired Student $t$ test with a two-tailed $P$ value estimation or the one-way ANOVA (Kruskal-Wallis test with Dunn's Multiple Comparison). The differences in the outcome variables were considered significant if the $P$ values were less than 0.05 .

\section{Results}

\subsection{T3SS-mediated secretion of LEE-encoded proteins is enhanced in hha and reduced in sepB deletion mutants}

Since previous studies have shown that a hha deletion results in an increased LEE transcription [19] and a sepB deletion abrogates T3SS activity [43], we wanted to determine relative activities of T3SS in the hha and hha sepB mutants by monitoring the levels of $L E E$-encoded proteins secreted into the bacterial culture supernatants. The total protein content of a TCA-precipitated culture supernatant of the hha mutant was about 2 -fold higher $(3.3 \mathrm{mg} / \mathrm{ml})$ than that of the $h \mathrm{ha}^{+}$wild-type $(1.6 \mathrm{mg} / \mathrm{ml})$ and 1.5 -fold higher than the hha sepB mutant $(2.1 \mathrm{mg} / \mathrm{ml})$. As shown in the Coomassie blue stained SDS-polyacrylamide gel (Fig. 1A), TCA-precipitates of the hha mutant culture supernatant contained several proteins that were readily visible (lane 2 ) compared to only a few barely detectable but identical protein bands in the TCA-precipitated culture supernatants of the $h h a^{+}$wild-type (lane 1 ) or the hha $\operatorname{sep} B$ mutant (lane 3) strains, respectively. Four of these protein bands appeared to approximate the masses predicted for EspA (21 kDa), EspB (34 kDa), Tir (62 kDa), and intimin (102 kDa) of E. coli 0157:H7. The protein profiles of the whole-cell lysates prepared from the $h h^{+}{ }^{+}$wild-type (lane 1), hha mutant (lane 2), and hha sepB mutant (lane 3) strains were similar (Fig. 1B). The probing of the nitrocellulose membranes carrying immobilized TCA-precipitated proteins with the antibodies specific for $L E E$-encoded EspA, EspB, Tir, and intimin, showed intense bands (Fig. 2) corresponding to these proteins in the hha mutant (middle panel), two of the four bands (EspA and EspB) in the $h h a^{+}$wild-type (left panel), and none of the four proteins in the hha sepB mutant strains (right panel). 

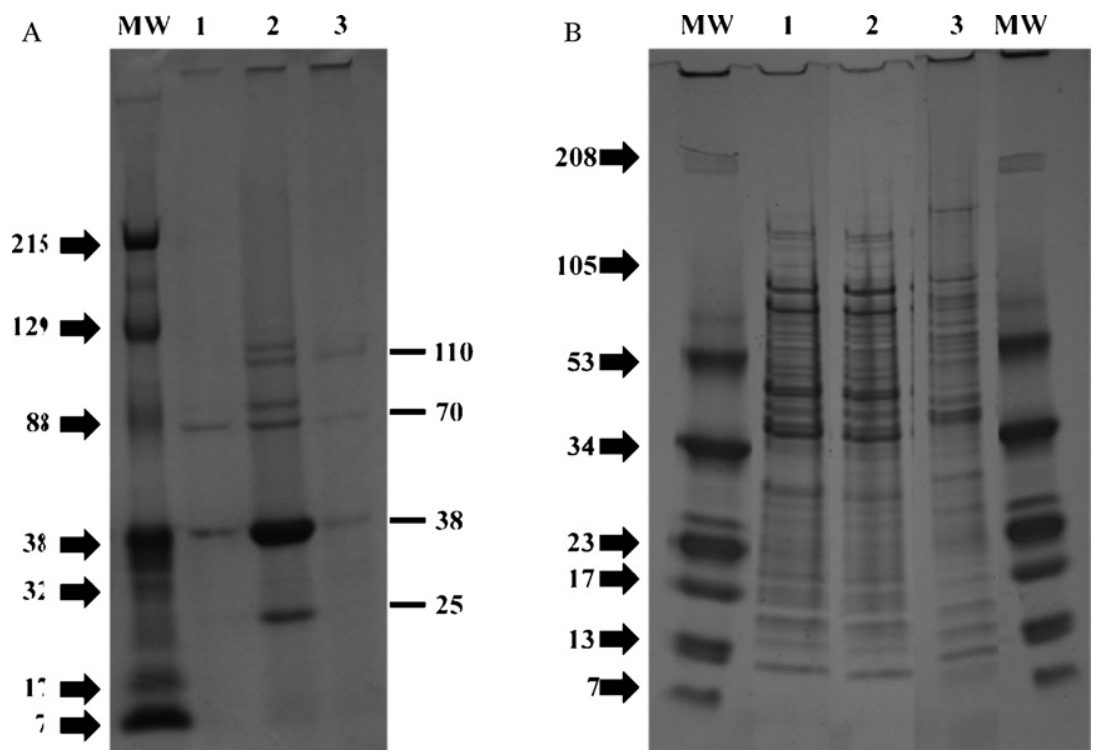

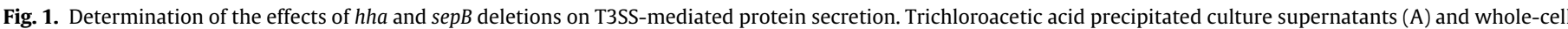

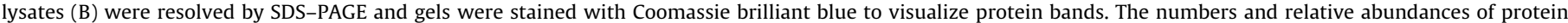

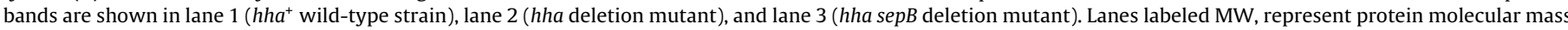
standards in kilodaltons (kDa), indicated on left. The approximate molecular masses of secreted proteins are indicated on the right side of (A).

\section{2. $\operatorname{sepB~deletion~enhances~intracellular~accumulation~of~}$ LEE-encoded proteins}

Since $\operatorname{sep} B$ deletion has been shown to compromise T3SSmediated secretion of several LEE-encoded proteins [12], we next examined whether a $\operatorname{sep} B$ deletion would result in an increased intracellular accumulation of $L E E$-encoded proteins. As shown in Fig. 3, the western blot analysis of the whole-cell lysates showed the presence of bands corresponding to intimin, Tir, EspB and EspA in the $h h a^{+}$wild-type, and hha and hha sepB mutant strains (Fig. 3). However, a visual examination of this gel showed higher amounts of these four proteins in the hha and hha sepB mutants than in the $h \mathrm{ha}^{+}$wild-type strain. Several low-molecular weight proteins, which could either represent truncated or degraded species, were also detected in the lanes corresponding to intimin, Tir, and EspB in blots prepared from the wild-type and the two mutant strains.

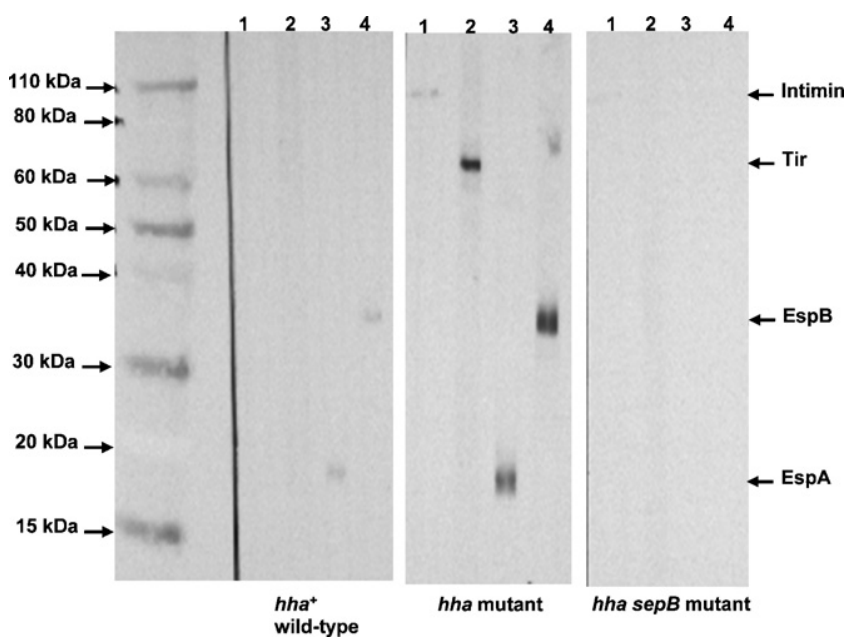

Fig. 2. Identification and determination of relative abundance of $L E E$-encoded proteins by Western blotting. Trichloroacetic acid precipitated culture supernatants prepared from $h h a^{+}$wild-type (left panel), hha mutant, (middle panel), and hha sepB mutant (right panel) strains were probed with rabbit anti-intimin (lane 1), antiTir (lane 2), anti-EspA (lane 3) and anti-EspB (lane 4). Lane labeled MW represents molecular mass standards in kilodaltons $(\mathrm{kDa})$.

\subsection{Vaccination enhanced immune response to LEE-encoded proteins}

The animal sera prepared from the blood collected pre- or 4-weaks post-vaccination were analyzed by western blotting to determine the IgG titers for specific $L E E$-encoded proteins. As shown in Table 2, the group of calves administered the PBS sham vaccine showed no change in the median titers for IgG against intimin, Tir, EspA, and EspB between the pre- and post-vaccination sera. On the other hand, the post-vaccination sera of the calves vaccinated with the $h h a^{+}$wild-type or the hha or the hha sepB mutant bacterins had increased median titers for these four IgG antibodies with the exception that the IgG titers against EspA remained the same in the pre- and post-vaccination sera of the calves vaccinated with the $h h a^{+}$wild-type bacterin. The highest titers for the four antibodies were detected in the post-vaccination sera of the calves vaccinated with the hha mutant bacterin. The postvaccination median titers for the anti-intimin IgG in the group of calves vaccinated with the hha sepB bacterin were 2 -fold or 3-fold lower than the calves vaccinated with the $h h a^{+}$wild-type or the $h h a$

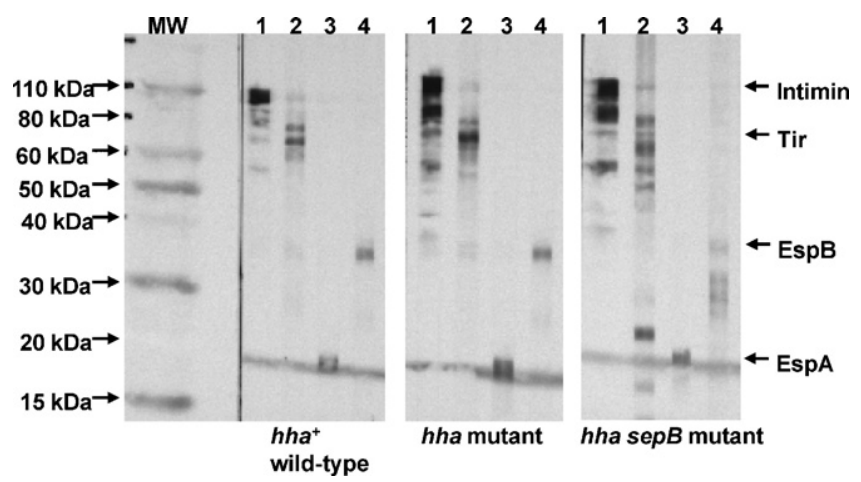

Fig. 3. Identification and determination of relative abundance of $L E E$-encoded proteins in whole-cell lysates by Western blotting. The whole- cell lysates prepared from $h h^{+}$wild-type (left panel), hha mutant (middle panel), and hha sepB mutant (right panel) strains were probed with rabbit anti-intimin (lane 1), anti-Tir (lane 2), anti-EspA (lane 3) and anti-EspB (lane 4). Lane labeled MW, represent molecular mass standards in kilodaltons ( $\mathrm{kDa})$. 
Table 2

Serum titers produced against $L E E$-encoded proteins in calves after vaccination.

\begin{tabular}{|c|c|c|c|c|c|c|c|c|}
\hline \multirow[t]{3}{*}{ Bacterins used } & \multicolumn{8}{|c|}{ Median serum titers ${ }^{\mathrm{a}}$} \\
\hline & \multicolumn{2}{|c|}{ Anti-intimin } & \multicolumn{2}{|l|}{ Anti-Tir } & \multicolumn{2}{|c|}{ Anti-EspB } & \multicolumn{2}{|c|}{ Anti-EspA } \\
\hline & Prevac. ${ }^{b}$ & Postvac. $^{\text {b }}$ & Prevac. & Postvac. & Prevac. & Postvac. & Prevac. & Postvac. \\
\hline$h h a^{+}$wild-type & 10 & 255 & 55 & 500 & 100 & 500 & 10 & 10 \\
\hline hha mutant & 100 & 300 & 300 & 1000 & 100 & 1000 & 10 & 300 \\
\hline hha sepB mutant & 10 & 100 & 100 & 500 & 100 & 750 & 55 & 100 \\
\hline PBS & 100 & 100 & 100 & 100 & 100 & 100 & 55 & 55 \\
\hline
\end{tabular}

a The median titers represent the reciprocals of the highest dilutions of serum yielding colored precipitates on blotted membranes.

b Pre-vaccination and 4-weeks post-vaccination.

mutant bacterins, respectively. The group of calves vaccinated with the hha sepB mutant bacterin also showed 1.5-fold lower anti-EspB IgG median titers than in the calves vaccinated with the $h h a^{+}$wildtype bacterin. The most notable observation was that the anti-EspA IgG titers were 30 -fold or 10 -fold higher in the calves vaccinated with the hha or the hha sepB mutant bacterins, respectively, compared to titers for this antibody in the calves vaccinated with the $h \mathrm{~h}^{+}$wild-type bacterin.

\subsection{Vaccination reduced the duration of shedding and the numbers of animals shedding E. coli 0157:H7}

The effects of vaccinations on the ability of $E$. coli $0157: \mathrm{H} 7$ to colonize and persist in the vaccinated calves were determined by comparing the mean number of calves that were positive for the presence of E. coli 0157:H7 in their feces over a 2-week sampling period, and the number of days each calf continued to shed $E$. coli 0157:H7 in feces. As shown in Fig. 4 , significantly $(P<0.05)$ fewer calves were found positive among the calves vaccinated with the hha (mean, 2.4 calves) or the hha sepB (mean, 2 calves) mutant bacterins compared to the calves vaccinated with the $h h^{+}$wildtype bacterin (mean, 4.6 calves). The numbers of calves shedding E. coli $0157: \mathrm{H7}$ were lower (mean, 3.3 calves) in the group of calves vaccinated with the PBS sham than in the group vaccinated with the $h \mathrm{ha}^{+}$wild-type bacterin (mean, 4.6), but this difference was not statistically significant $(P>0.05)$.

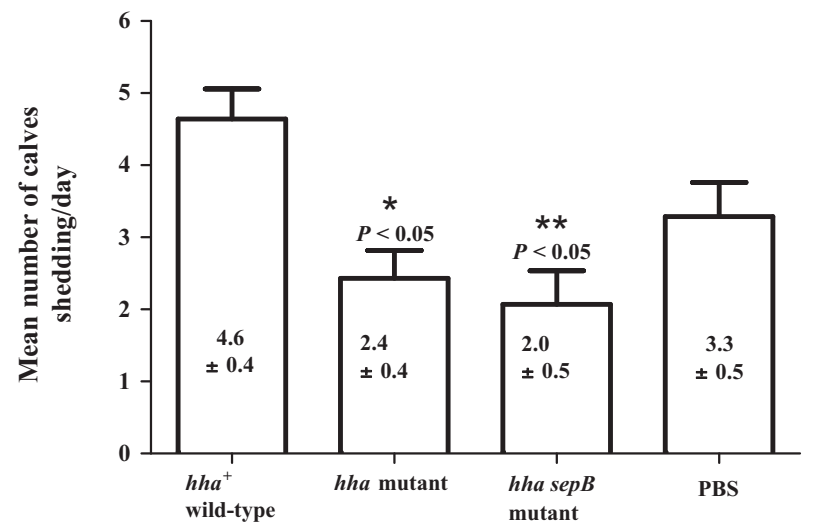

Bacterins used

Fig. 4. Determination of numbers of calves shedding E. coli 0157:H7 postvaccination. The mean numbers of calves shedding detectable levels of $E$. col 0157:H7 after vaccination with a PBS sham vaccine or bacterins prepared from $h a^{+}$wild-type or hha or hha sepB deletion mutants were estimated by averaging the numbers of calves shedding $E$. coli 0157:H7 each day of the two weeks of fecal sampling period. The mean values for the numbers of calves shedding E. coli $015: \mathrm{H} 7$ plus and minus the standard error of the means (SEM) are indicated in the corresponding bar. The significance of the variance $(P<0.05)$ of the means is shown as a single or double asterisk.
The evaluation of the duration of fecal shedding of $E$. coli 0157:H7 revealed that the calves vaccinated with either the hha or the hha sepB mutant bacterin had 50\% (3 of 6 calves in each group) of the calves stopped shedding detectable levels of $E$. coli 0157:H7 within 1-2 days after oral inoculations with the wild-type E. coli 0157:H7 (Fig. 5). The mean durations of fecal shedding for the calves vaccinated with the hha or the hha $\operatorname{sep} B$ mutant bacterins were 5.7 days \pm 2.1 and 4.8 days \pm 1.7 , respectively. This reduction in the duration of fecal shedding in these two groups of vaccinated calves was statistically significant $(P<0.05)$ when compared to the duration of shedding in the calves vaccinated with the $h \mathrm{ha}^{+}$wildtype bacterin ( 6 of 6 calves shedding for 9-14 days, with the mean duration of shedding lasting 10.8 days \pm 0.75 ). Of the remaining three calves in the group vaccinated with the hha mutant bacterin, two calves were positive for fecal shedding for 8 and the third calf for 14 days of the 14-day fecal sampling period. Similarly, the remaining three calves in the group vaccinated with the hha $\operatorname{sep} B$ mutant bacterin continued shedding E. coli 0157:H7 for 8-9 days. In the PBS sham vaccinated group, four calves remained positive for fecal shedding for 9-11 days (mean duration of shedding at 7.67 days \pm 1.5 ) and the other two calves had detectable levels of $E$. coli 0157H7 in their feces for 3 days. Thus, difference in the duration of fecal shedding in the PBS sham group was not statistically significant $(P \geq 0.5)$ when compared to the duration of shedding in the group of calves vaccinated with the $h h a^{+}$wild-type bacterin.

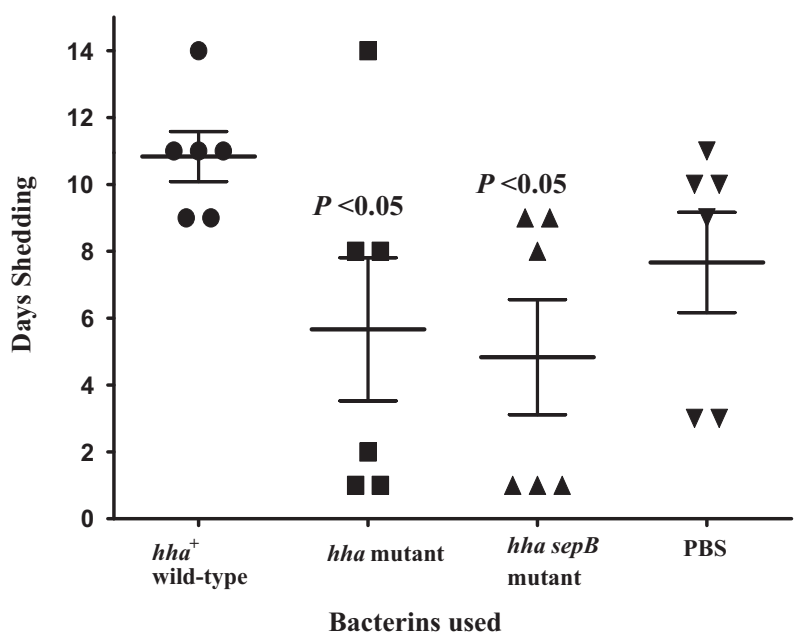

Fig. 5. Determination of the duration of fecal shedding of E. coli $0157: \mathrm{H} 7$ in vaccinated animals. The mean duration of fecal shedding in calves administered a PBS sham vaccine or bacterins prepared from $h h a^{+}$wild-type or hha or hha sepB deletion mutants was estimated by averaging the total number of days in a 2-week fecal sampling period (following oral inoculation with a live E. coli $0157: H 7$ ) that the calves were determined positive for the presence of detectable levels $\left(10^{2} \mathrm{cfu} / \mathrm{g}\right.$ feces) of the inoculum strain. The mean duration of shedding for each group of calves is shown as a horizontal bar intersected by a vertical bar representing the standard error of the means (SEM). The significance of the variance $(P<0.05)$ of the means is shown as a single or double asterisk above the SEM line. 


\section{Discussion}

In this study, we described for the first time the potential application of bacterins for reducing the fecal shedding of E. coli 0157:H7 in cattle. The premise for the development of the bacterins was to expose the immune system of cattle to multiple LEE-encoded proteins that are critical to the ability of E. coli 0157:H7 to colonize cattle intestines, which in turn promote the long-term fecal shedding of these bacteria. The importance of $L E E$-encoded proteins as potential vaccine candidates has been evident in earlier studies that have used component vaccines containing either one or two LEEencoded proteins or a combination of a $L E E$ - and a non- $L E E$ encoded proteins to immunize non-bovine animal species. For example, it has been demonstrated that the transfer of maternal anti-intimin antibodies to suckling piglets of sows immunized with a purified intimin, protected these piglets from E. coli 0157:H7-caused disease compared to piglets that suckled on non-vaccinated sows [29]. Similarly, an oral feeding of a plant cell-based intimin vaccine to mice reduced the duration of shedding of E. coli 0157:H7 in the feces of vaccinated animals [30]. Since these earlier studies, the component vaccines containing one or two LEE-encoded proteins or a combination of one $L E E$ - and one non- $L E E$-encoded protein have been tested in experimental vaccinations of cattle for successfully inducing humoral immune responses to vaccine-specific proteins, but none of these studies showed a reduction in the fecal shedding of E. coli 0157:H7 in vaccinated animals [47,48]. On the other hand, the vaccine preparations containing multiple $L E E$-encoded proteins have been found effective in inducing humoral immune responses to the $L E E$-encoded antigens contained in these vaccines, and in reducing the shedding of $E$. coli $0157: \mathrm{H} 7$ in the immunized cattle [31]. However, the preparation of these vaccines requires either the purification of individual $L E E$-encoded proteins using expression vector systems or a recovery of these proteins by an acid precipitation of culture supernatants of E. coli 0157:H7. To circumvent the problem of purifying or precipitating proteins for use in the vaccine preparations, we used the hha deletion mutant as the basis for developing the bacterins because this mutant has been shown to express $L E E$ at very high levels [19]. As demonstrated in the current study, the levels of several LEE-encoded proteins, especially EspA, EspB, intimin, and Tir, were higher in the cell-free supernatants and the whole-cell lysates of the hha deletion mutant indicating that these proteins represented major immunogens in the bacterins prepared from this mutant strain. This hypothesis is supported by the results showing that a parenteral administration of the hha-mutant based bacterins to cattle resulted in the highest increases of humoral immune responses to $L E E$-encoded proteins EspA, EspB, and Tir compared to the immune responses generated against these proteins in cattle administered the $h \mathrm{ha}^{+}$wild-type bacterin or the PBS sham vaccine. Whether these humoral antibodies are transported to the intestinal mucosa to inhibit $E$. coli 0157:H7 colonization or if the parenteral vaccination is also capable of inducing a mucosal immune response to the antigens present in the vaccine preparations, however, remains to be determined.

The increased immune response to $L E E$-encoded proteins in the calves vaccinated with the hha or hha sepB mutant bacterins reduced the numbers of animals shedding E. coli 0157 : $\mathrm{H} 7$ and the duration of fecal shedding of these bacteria in feces compared to the calves vaccinated with the $h h a^{+}$wild-type bacterin or with the PBS sham vaccine. One of the most striking findings of the vaccination was that an increase in the anti-EspA IgG titers was seen only in the calves vaccinated with the hha or hha $\operatorname{sep} B$ mutant bacterins, indicating that an increased immune response to EspA is critical for reducing the fecal shedding of $E$. coli $0157: H 7$. Interestingly, the calves vaccinated with the hha sepB mutant bacterin showed 2 to 3-fold lower IgG titers against intimin, Tir, EspA, and EspB IgG compared to the calves vaccinated with the hha mutant bacterin. Since intimin, Tir, EspA, and EspB are considered important in inducing a humoral immune response in vaccinated animals [31,40,47-50], a compromised translocation of these proteins to the bacterial outer membranes of the hha sepB mutant may account for reduced IgG titers observed against these proteins in the sera of animals vaccinated with the hha sepB bacterin. The reduced translocation of these proteins is presumably responsible for a lowered magnitude of the immune response observed for these proteins in the calves vaccinated with the hha sepB bacterin. However, the hha sepB bacterin appears to be as effective as the hha mutant bacterin in terms of its ability to reduce the overall duration of fecal shedding and to reduce the numbers of animals shedding $E$. coli $0157: H 7$. Although the genetic and molecular nature of the factors contributing to the effectiveness of the $h$ ha $\operatorname{sep} B$ bacterin are hitherto unknown, it is possible that the hha sepB double deletion causes quantitative and/or qualitative changes in some unknown bacterial cell surface proteins that could potentially induce an immune response comparable in effectiveness to the hha mutant bacterin. For example, a recent study had demonstrated that a parenteral administration of a bacterial cell surface siderophore receptor protein-based (SRP) vaccine induced humoral immune response in cattle to SRP, and induction of anti-SRP antibodies was effective in reducing the fecal shedding of $E$. coli $0157: \mathrm{H} 7$ in vaccinated versus un-vaccinated cattle $[42,51,52]$.

Although an enhanced expression of the $L E E$-encoded proteins appears to be directly responsible for the induction of a systemic immune response to the LEE proteins in calves vaccinated with the bacterins prepared from the hha mutant, deleting hha and stx2 in E. coli 0157:H7 strain used for preparing these bacterins might also indirectly potentiate immunogenicity of these bacterins. For example, a previous study demonstrated that a hha deletion reduces the expression of $f l i C$, the gene encoding flagellin, a major structural subunit of the flagella in E. coli 0157:H7 [53]. Since the presence of flagellin in vaccine preparations has been suggested to impair the efficacy of these vaccines against E. coli 0157:H7 due to the neutralization of TLR5 activation and an impairment of host innate immune response [54], the reduced expression of flagellin caused by the hha deletion would presumably facilitate an increased immune response in the animals vaccinated with the bacterins derived from the hha deletion mutants of $E$. coli 0157:H7. These observations might explain why the greater numbers of animals in the group of calves vaccinated with the $h h^{+}$wild-type bacterin were positive for fecal shedding compared to the PBS sham vaccinated group of calves. Similarly, deleting st $x 2$ in the bacterin strains that we have used in this study is advantageous as it has been demonstrated that the presence of $s t x 2$ reduces lymphoproliferative immune response in cattle inoculated with the stx2-positive E. coli 0157:H7 compared to cattle inoculated with the stx2 deletion mutants [55].

Other potential advantages of the bacterins that we have described in this study are the ease and the low-cost of preparation compared to the vaccines that require purification and concentration of $L E E$-encoded or other proteins. In addition, novel bacterins could easily be constructed from specific mutants of E. coli 0157:H7 for delivering large quantities of not only the $L E E$-encoded proteins but also other bacterial antigens to induce systemic and/or localized immune responses to multiple colonization factors for reducing E. coli $\mathrm{O} 157$ colonization of cattle intestines.

\section{Acknowledgements}

We thank Robert Morgan and Bryan Wheeler for technical assistance; Alison O'Brien and Jorge Giron for providing rabbit antiserum for detecting Tir, intimin, EspA and EspB; and Richard Zuerner and Louisa Tabatabai for critical review of the manuscript. 


\section{References}

[1] Nataro JP, Kaper JB. Diarrheagenic Escherichia coli. Clin Microbiol Rev 1998; 11:142-201.

[2] Laegreid WW, Elder RO, Keen JE. Prevalence of Escherichia coli 0157:H7 in range beef calves at weaning. Epidemiol Infect 1999;123:291-8.

[3] Dean-Nystrom EA, Bosworth BT, Moon HW. Pathogenesis of Escherichia coli O157:H7 in weaned calves. Adv Exp Med Biol 1999;473:173-7.

[4] Naylor SW, Low JC, Besser TE, Mahajan A, Gunn GJ, Pearce MC, et al. Lymphoid follicle-dense mucosa at the terminal rectum is the principal site of colonization of enterohemorrhagic Escherichia coli 0157:H7 in the bovine host. Infect Immun 2003;71:1505-12.

[5] Rice DH, Sheng HQ Wynia SA, Hovde CJ. Rectoanal mucosal swab culture is more sensitive than fecal culture and distinguishes Escherichia coli 0157:H7colonized cattle and those transiently shedding the same organism. J Clin Microbiol 2003;41:4924-9.

[6] Elder RO, Keen JE, Siragusa GR, Barkocy-Gallagher GA, Koohmaraie M, Laegreid WW. Correlation of enterohemorrhagic Escherichia coli 0157 prevalence in feces, hides, and carcasses of beef cattle during processing. Proc Natl Acad Sci U S A 2000;97:2999-3003.

[7] Dean-Nystrom EA, Bosworth BT, Moon HW, O'Brien AD. Escherichia coli 0157:H7 requires intimin for enteropathogenicity in calves. Infect Immun 1998;66:4560-3.

[8] Naylor SW, Roe AJ, Nart P, Spears K, Smith DG, Low JC, et al. Escherichia coli 0157: H7 forms attaching and effacing lesions at the terminal rectum of cattle and colonization requires the LEE4 operon. Microbiology 2005;151: 2773-81.

[9] Elliott SJ, Wainwright LA, McDaniel TK, Jarvis KG, Deng YK, Lai LC, et al. The complete sequence of the locus of enterocyte effacement (LEE) from enteropathogenic Escherichia coli E2348/69. Mol Microbiol 1998;28:1-4.

[10] Elliott SJ, Yu J, Kaper JB. The cloned locus of enterocyte effacement from enterohemorrhagic Escherichia coli 0157:H7 is unable to confer the attaching and effacing phenotype upon E. coli K-12. Infect Immun 1999;67:4260-3.

[11] Ritchie JM, Waldor MK. The locus of enterocyte effacement-encoded effector proteins all promote enterohemorrhagic Escherichia coli pathogenicity in infant rabbits. Infect Immun 2005;73:1466-74.

[12] Jarvis KG, Kaper JB. Secretion of extracellular proteins by enterohemorrhagic Escherichia coli via a putative type III secretion system. Infect Immun 1996;64:4826-9.

[13] McDaniel TK, Jarvis KG, Donnenberg MS, Kaper JB. A genetic locus of enterocyte effacement conserved among diverse enterobacterial pathogens. Proc Natl Acad Sci U S A 1995;92:1664-8.

[14] Knutton S, Rosenshine I, Pallen MJ, Nisan I, Neves BC, Bain C, et al. A novel EspAassociated surface organelle of enteropathogenic Escherichia coli involved in protein translocation into epithelial cells. EMBO J 1998;17:2166-76.

[15] Campellone KG, Leong JM. Tails of two Tirs: actin pedestal formation by enteropathogenic E. coli and enterohemorrhagic E. coli 0157:H7. Curr Opin Microbiol 2003;6:82-90.

[16] DeVinney R, Stein M, Reinscheid D, Abe A, Ruschkowski S, Finlay BB. Enterohemorrhagic Escherichia coli 0157:H7 produces Tir, which is translocated to the host cell membrane but is not tyrosine phosphorylated. Infect Immun 1999;67:2389-98

[17] Abe A, Heczko U, Hegele RG, Brett Finlay B. Two enteropathogenic Escherichia coli type III secreted proteins EspA and EspB, are virulence factors. J Exp Med 1998;188:1907-16.

[18] Barba J, Bustamante VH, Flores-Valdez MA, Deng W, Finlay BB, Puente JL. A positive regulatory loop controls expression of the locus of enterocyte effacement-encoded regulators Ler and GrlA. J Bacteriol 2005;187:7918-30.

[19] Sharma VK, Zuerner RL. Role of hha and ler in transcriptional regulation of the esp operon of enterohemorrhagic Escherichia coli 0157:H7. J Bacteriol 2004;186:7290-301.

[20] Sharma VK, Carlson SA, Casey TA. Hyperadherence of an hha mutant of Escherichia coli 0157:H7 is correlated with enhanced expression of LEEencoded adherence genes. FEMS Microbiol Lett 2005;243:189-96.

[21] Dziva F, van Diemen PM, Stevens MP, Smith AJ, Wallis TS. Identification of Escherichia coli 0157: H7 genes influencing colonization of the bovine gastrointestinal tract using signature-tagged mutagenesis. Microbiology 2004; 150:3631-45.

[22] Bretschneider G, Berberov EM, Moxley RA. Reduced intestinal colonization of adult beef cattle by Escherichia coli 0157:H7 tir deletion and nalidixic-acidresistant mutants lacking flagellar expression. Vet Microbiol 2007;125:381-6.

[23] Cornick NA, Booher SL, Moon HW. Intimin facilitates colonization by Escherichia coli 0157:H7 in adult ruminants. Infect Immun 2002;70:2704-7.

[24] La Ragione RM, Ahmed NM, Best A, Clifford D, Weyer U, Cooley WA, et al. Colonization of 8-week-old conventionally reared goats by Escherichia coli 0157: H7 after oral inoculation. J Med Microbiol 2005;54:485-92.

[25] McKee ML, Melton-Celsa AR, Moxley RA, Francis DH, O’Brien AD. Enterohemorrhagic Escherichia coli 0157:H7 requires intimin to colonize the gnotobiotic pig intestine and to adhere to HEp-2 cells. Infect Immun 1995;63:3739-44.

[26] Sheng H, Lim JY, Knecht HJ, Li J, Hovde CJ. Role of Escherichia coli 0157:H7 virulence factors in colonization at the bovine terminal rectal mucosa. Infect Immun 2006;74:4685-93.

[27] Shifrin Y, Peleg A, Ilan O, Nadler C, Kobi S, Baruch K, et al. Transient shielding of intimin and the type III secretion system of enterohemorrhagic and enteropathogenic Escherichia coli by a group 4 capsule. J Bacteriol 2008;190:5063-74.
[28] Vlisidou I, Dziva F, La Ragione RM, Best A, Garmendia J, Hawes P, et al. Role of intimin-tir interactions and the tir-cytoskeleton coupling protein in the colonization of calves and lambs by Escherichia coli 0157:H7. Infect Immun 2006;74:758-64.

[29] Dean-Nystrom EA, Gansheroff LJ, Mills M, Moon HW, O’Brien AD. Vaccination of pregnant dams with intimin(O157) protects suckling piglets from Escherichia coli 0157:H7 infection. Infect Immun 2002;70:2414-8.

[30] Judge NA, Mason HS, O'Brien AD. Plant cell-based intimin vaccine given orally to mice primed with intimin reduces time of Escherichia coli 0157:H7 shedding in feces. Infect Immun 2004;72:168-75.

[31] McNeilly TN, Mitchell MC, Rosser T, McAteer S, Low JC, Smith DG, et al. Immunization of cattle with a combination of purified intimin-531 EspA and Tir significantly reduces shedding of Escherichia coli 0157:H7 following oral challenge. Vaccine 2010;28:1422-8.

[32] McNeilly TN, Naylor SW, Mahajan A, Mitchell MC, McAteer S, Deane D, et al. Escherichia coli 0157:H7 colonization in cattle following systemic and mucosal immunization with purified H7 flagellin. Infect Immun 2008;76:2594-602.

[33] Hancock DD, Besser TE, Rice DH, Herriott DE, Tarr PI. A longitudinal study of Escherichia coli 0157 in fourteen cattle herds. Epidemiol Infect 1997; 118:193-5.

[34] Sargeant JM, Gillespie JR, Oberst RD, Phebus RK, Hyatt DR, Bohra LK, et al. Results of a longitudinal study of the prevalence of Escherichia coli 0157:H7 on cow-calf farms. Am J Vet Res 2000;61:1375-9.

[35] Sargeant JM, Sanderson MW, Griffin DD, Smith RA. Factors associated with the presence of Escherichia coli 0157 in feedlot-cattle water and feed in the Midwestern USA. Prev Vet Med 2004;66:207-37.

[36] Sargeant JM, Sanderson MW, Smith RA, Griffin DD. Associations between management, climate, and Escherichia coli 0157 in the faeces of feedlot cattle in the Midwestern USA. Prev Vet Med 2004;66:175-206

[37] Frenzen PD, Drake A, Angulo FJ. Economic cost of illness due to Escherichia coli 0157 infections in the United States. J Food Prot 2005;68:2623-30.

[38] Moxley RA, Smith DR, Luebbe M, Erickson GE, Klopfenstein TJ, Rogan D. Escherichia coli 0157:H7 vaccine dose-effect in feedlot cattle. Foodborne Pathog Dis 2009;6:879-84

[39] Peterson RE, Klopfenstein TJ, Moxley RA, Erickson GE, Hinkley S, Bretschneider $\mathrm{G}$, et al. Effect of a vaccine product containing type III secreted proteins on the probability of Escherichia coli $0157: \mathrm{H7}$ fecal shedding and mucosal colonization in feedlot cattle. J Food Prot 2007;70:2568-77.

[40] Potter AA, Klashinsky S, Li Y, Frey E, Townsend H, Rogan D, et al. Decreased shedding of Escherichia coli $0157: \mathrm{H7}$ by cattle following vaccination with type III secreted proteins. Vaccine 2004;22:362-9.

[41] Smith DR, Moxley RA, Klopfenstein TJ, Erickson GE. A randomized longitudinal trial to test the effect of regional vaccination within a cattle feedyard on Escherichia coli 0157:H7 rectal colonization, fecal shedding, and hide contamination. Foodborne Pathog Dis 2009;6:885-92.

[42] Thomson DU, Loneragan $\mathrm{GH}$, Thornton $\mathrm{AB}$, Lechtenberg KF, Emery DA Burkhardt DT, et al. Use of a siderophore receptor and porin proteins-based vaccine to control the burden of Escherichia coli 0157:H7 in feedlot cattle. Foodborne Pathog Dis 2009;6:871-7.

[43] Jarvis KG, Giron JA, Jerse AE, McDaniel TK, Donnenberg MS, Kaper JB. Enteropathogenic Escherichia coli contains a putative type III secretion system necessary for the export of proteins involved in attaching and effacing lesion formation. Proc Natl Acad Sci U S A 1995;92:7996-8000.

[44] Perna NT, Plunkett 3rd G, Burland V, Mau B, Glasner JD, et al. Genome sequence of enterohaemorrhagic Escherichia coli 0157:H7. Nature 2001;409: 529-33.

[45] Deluyker HA, Rossitto P, Van Oye SN, Cullor JS. Efficacy of an Escherichia coli $\mathrm{J}-5$ mutant strain bacterin in the protection of calves from endotoxin disease caused by subcutaneous challenge with endotoxins from Escherichia coli. Vaccine 2004;23:709-17.

[46] Selim SA, Cullor JS, Smith BP, Blanchard P, Farver TB, Hoffman R, et al. The effect of Escherichia coli J5 and modified live Salmonella dublin vaccines in artificially reared neonatal calves. Vaccine 1995;13:381-90.

[47] Dziva F, Vlisidou I, Crepin VF, Wallis TS, Frankel G, Stevens MP. Vaccination of calves with EspA, a key colonisation factor of Escherichia coli 0157:H7, induces antigen-specific humoral responses but does not confer protection against intestinal colonisation. Vet Microbiol 2007:123:254-61.

[48] van Diemen PM, Dziva F, Abu-Median A, Wallis TS, van den Bosch H, Dougan G, et al. Subunit vaccines based on intimin and Efa-1 polypeptides induce humoral immunity in cattle but do not protect against intestinal colonisation by enterohaemorrhagic Escherichia coli 0157:H7 or 026:H. Vet Immunol Immunopathol 2007;116:47-58.

[49] Cheng Y, Feng Y, Luo P, Gu J, Yu S, Zhang WJ, et al. Fusion expression and immunogenicity of EHEC EspA-Stx2Al protein: implications for the vaccine development. J Microbiol 2009;47:498-505.

[50] Luan J, Zhuang Z, Liu Y, Yun K, Chen M, Wang PG. Expression of EspA in Lactococcus lactis NZ9000 and the detection of its immune effect in vivo and vitro. Immunopharmacol Immunotoxicol 2010;32:133-40.

[51] Fox JT, Thomson DU, Drouillard JS, Thornton AB, Burkhardt DT, Emery DA, et al. Efficacy of Escherichia coli 0157:H7 siderophore receptor/porin proteins-based vaccine in feedlot cattle naturally shedding E. coli 0157. Foodborne Pathog Dis 2009;6:893-9.

[52] Thornton AB, Thomson DU, Loneragan GH, Fox JT, Burkhardt DT, Emery DA, et al. Effects of a siderophore receptor and porin proteins-based vaccination on fecal shedding of Escherichia coli 0157:H7 in experimentally inoculated cattle. J Food Prot 2009;72:866-9. 
[53] Sharma VK, Bearson SM, Bearson BL. Evaluation of the effects of sdiA, a luxR homologue, on adherence and motility of Escherichia coli 0157: H7. Microbiology 2010;156:1303-12.

[54] McNeilly TN, Mitchell MC, Nisbet AJ, McAteer S, Erridge C, Inglis NF, et al. IgA and IgG antibody responses following systemic immunization of cattle with native $\mathrm{H7}$ flagellin differ in epitope recognition and capacity to neutralise TLR5 signalling. Vaccine 2010;28:1412-21.
[55] Hoffman MA, Menge C, Casey TA, Laegreid W, Bosworth BT, Dean-Nystrom EA. Bovine immune response to shiga-toxigenic Escherichia coli 0157:H7. Clin Vaccine Immunol 2006;13:1322-7.

[56] Griffin PM, Ostroff SM, Tauxe RV, Greene KD, Wells JG, Lewis JH, et al. Illnesses associated with Escherichia coli $0157:$ H7 infections. A broad clinical spectrum. Ann Intern Med 1988;109:705-12. 